\title{
KINETIKA PENGERINGAN CHIPS SUKUN (Artocarpus communis) DALAM PEMBUATAN TEPUNG SUKUN TERMODIFIKASI DENGAN ASAM LAKTAT MENGGUNAKAN CABINET DRYER
}

\author{
DRYING KINETICS OF BREADFRUIT CHIPS (Artocarpus communis) IN MAKING \\ MODIFIED BREADFRUIT FLOUR WITH LACTIC ACID \\ USING CABINET DRYER
}

\author{
Bambang Sigit Amanto ${ }^{1)}$, Godras Jati Manuhara ${ }^{1)}$, Ratri Rosdiana Putri ${ }^{1)}$ \\ ${ }^{(1)}$ Program Studi Ilmu dan Teknologi Pangan, Fakultas Pertanian, Universitas Sebelas Maret \\ email : ratrirosdiana@yahoo.com
}

\begin{abstract}
.

The purpose of this research was to determine the drying kinetics are the rate of drying and drying energy requirements of breadfruit chips drying, and to determine the characteristics (moisture content, amylose content, whiteness, viscosity, solubility, swellling power, functional groups) of breadfruit flour. Design of studies using Randomized Factorial Design (RAF), which consists of two factors: treatment (nonmodification and modification of $1 \%$ lactic acid) and drying temperature $\left(60^{\circ} \mathrm{C}, 65^{\circ} \mathrm{C}\right.$ and $\left.70^{\circ} \mathrm{C}\right)$. The results showed that the higher the drying temperature and the addition of lactic acid caused decreased of the moisture content of breadfruit chips, accelerated of drying rate and decreased of drying energy requirements. The higher drying temperatures and the addition of lactic acid caused decreased moisture content and whiteness degree of white flour breadfruit, increased amylose content, viscosity, solubility and swelling power of breadfruit flour. Analysis of functional groups (FTIR) showed the presence of carbonyl group absorption at wave number $1735 \mathrm{~cm}^{-1}$ of the breadfruit flour modified lactic acid.
\end{abstract}

Keywords: drying kinetics, modification, temperatur, breadfruit, flour

\begin{abstract}
ABSTRAK
Penelitian ini bertujuan untuk mengetahui kinetika pengeringan yaitu laju pengeringan dan kebutuhan energi pada pengeringan chips sukun, dan untuk mengetahui karakteristik (kadar air, kadar amilosa, derajat putih, viskositas, kelarutan, swellling power, gugus fungsi) tepung sukun. Perancangan penelitian menggunakan rancangan acak faktorial (RAF) yang terdiri dari dua faktor yaitu perlakuan (nonmodifikasi dan modifikasi asam laktat $1 \%)$ dan suhu pengeringan $\left(60^{\circ} \mathrm{C}, 65^{\circ} \mathrm{C}\right.$ dan $\left.70^{\circ} \mathrm{C}\right)$. Setiap perlakuan dilakukan tiga ulangan sampel dengan dua kali ulangan analisa. Hasil penelitian menunjukkan bahwa semakin tinggi suhu pengeringan dan penambahan asam laktat menyebabkan penurunan kadar air chips sukun, mempercepat laju pengeringan dan menurunkan kebutuhan energi pengeringan. Semakin tinggi suhu pengeringan dan penambahan asam laktat menyebabkan menurunnya kadar air dan derajat putih tepung sukun, meningkatnya kadar amilosa, viskositas, kelarutan dan swelling power tepung sukun. Analisis gugus fungsi (FTIR) menunjukkan adanya serapan gugus karbonil pada bilangan gelombang $1735 \mathrm{~cm}^{-1}$ dari tepung sukun yang termodifikasi asam laktat.
\end{abstract}

Kata kunci: kinetika pengeringan, modifikasi, suhu, sukun, tepung

\section{PENDAHULUAN}

Sukun merupakan tanaman tahunan yang artinya ketersediaan buah sukun sebagai bahan pangan dapat diandalkan sepanjang tahun (Suarni, 2003). Menurut data Badan Pusat Statistik (BPS, 2013), produksi sukun di Indonesia dari tahun 2010 sampai 2012 mengalami peningkatan dari 89.231 ton menjadi 111.533 ton.

Buah sukun termasuk salah satu buah sumber karbohidrat yang dapat diolah menjadi tepung. Berdasarkan Pitojo (1992) komposisi kandungan gizi buah sukun tua adalah energi 108 kkal. Buah sukun juga mudah mengalami pencoklatan karena adanya senyawa fenol, sehingga tepung yang dihasilkan berwarna kecoklatan. Salah satu upaya yang dilakukan untuk mengurangi hal tersebut adalah dengan metode modifikasi. Metode modifikasi yang sering digunakan adalah modifikasi secara kimia. Selain itu, menurut Hartanti (2013), peningkatan konsentrasi asam laktat berpengaruh secara signifikan terhadap kenaikan derajat putih tepung sukun.

Salah satu hal yang perlu diperhatikan dalam pembuatan tepung sukun termodifikasi adalah prosedur pengeringan. Tujuan pengeringan adalah menghilangkan air, mencegah fermentasi atau pertumbuhan 
jamur dan memperlambat perubahan kimia pada makanan (Gunasekaran et al., 2012). Selama pengeringan dua proses terjadi secara simultan seperti transfer panas ke produk dari sumber pemanasan dan perpindahan massa uap air dari bagian dalam produk ke permukaan dan dari permukaan ke udara sekitar (Rajkumar dan Kulanthaisami, 2006 dalam Susilo, 2012). Cabinet dryer merupakan salah satu alat pengeringan modern yang dapat digunakan dalam proses pengeringan. Dengan cabinet dryer ini akan mempermudah pengaturan suhu sehingga tepung yang dihasilkan lebih baik kualitasnya.

Semakin tinggi suhu udara pengering makin besar energi panas yang dibawa udara sehingga semakin banyak jumlah massa cairan yang diuapkan dari permukaan bahan yang dikeringkan (Taib et. al.,1987). Menurut Erika (2010) pati termodifikasi dengan hidrolisis asam menghasilkan pati dengan struktur yang lebih renggang, sehingga air lebih mudah menguap pada waktu pengeringan. Selain itu, menurut Widhaswari (2013) perendaman mengakibatkan tekstur bahan menjadi lunak dan berpori sehingga penguapan air selama pengeringan lebih mudah, dengan demikian kadar air akan menurun dalam jangka waktu pengeringan yang sama. Oleh karena itu, dilakukan penelitian ini untuk mengetahui kinetika pengeringan chips sukun (Artocarpus communis) dalam pembuatan tepung sukun termodifikasi dengan asam laktat menggunakan cabinet dryer. .

\section{METODE PENELITIAN}

\section{Bahan}

Buah sukun (Artocarpus communis) yang digunakan dalam penelitian ini merupakan buah sukun lokal dengan berat $\pm 1 \mathrm{~kg}$ yang diperoleh dari Tumang, Boyolali. Larutan yang digunakan dalam perendaman yaitu asam laktat pro analys (pa) tanpa perlakuan lebih lanjut dari laboratorium kimia MIPA UNS dan aquades. Sedangkan bahan-bahan yang digunakan untuk analisis antara lain $\mathrm{I}_{2}$, $\mathrm{NaOH}$, etanol $95 \%$, asam asetat, $\mathrm{KI}, \mathrm{KBr}$ dan aquades.

\section{Alat}

Alat yang digunakan dalam penelitian ini adalah slicer, waterbath, cabinet dryer, termometer, hygrometer, timbangan analitik, blender, ayakan 80 mesh, botol timbang, oven "Memmert", desikator, chromameter "Konika minolta CR 400", viscometer "Brokefield DV-II+Pro", tabung reaksi,waterbath, sentrifuse, penjepit, spektrofotometer UV-Vis "UV-Mini 1240", pipet, labu ukur, Spektrometer FTIR Shimadzu IR Prestige-21.

\section{Tahapan Penelitian}

\section{Persiapan Bahan}

Buah sukun yang telah didapat dikupas dan dibelah, kemudian empulur dan biji sukun dipisahkan dari daging buah. Daging buah sukun yang telah dipisahkan dari biji dan empulurnya, kemudian dicuci hingga bersih. Daging sukun diiris tipis-tipis dengan ketebalan $\pm 3 \mathrm{~mm}$ menggunakan slicer.

\section{Perendaman dalam waterbath}

Irisan chips sukun diberi perlakuan nonmodifikasi dan modifikasi dengan asam laktat $1 \%$. Pembuatan larutan asam laktat $1 \%$ dalam $750 \mathrm{ml}$ aquades. Sebanyak 250 gram buah sukun yang telah dikecilkan ukurannya $\pm 3 \mathrm{~mm}$ kemudian dimasukkan dalam larutan asam laktat 1\% (Hartanti, 2013). Selanjutnya dipanaskan dalam waterbath pada suhu $45{ }^{\circ} \mathrm{C}$ dengan lama perendaman 60 menit. Tujuan dilakukannya pemanasan adalah untuk mempercepat reaksi hidrolisis asam.

\section{Pengeringan}

Setelah dilakukan perendaman dalam waterbath, chips sukun ditiriskan kemudian dikeringkan dengan cabinet dryer dengan variasi suhu $60{ }^{\circ} \mathrm{C}, \quad 65{ }^{\circ} \mathrm{C}$ dan $70{ }^{\circ} \mathrm{C}$ (Rusmayanti, 2006). Selama pengeringan berlangsung, dilakukan penimbangan chips sukun setiap 15 menit pada 5 titik berbeda dan pengukuran RH. Proses penimbangan akan dihentikan ketika kadar air chips sukun $\leq 10 \%$. Selanjutnya dilakukan perhitungan terhadap laju pengeringan dan kebutuhan energi selama proses pengeringan. 


\section{Penggilingan dan Pengayakan}

Chips sukun yang telah kering selanjutnya ditepungkan dengan menggunakan blender dan diayak dengan ayakan 80 mesh.

\section{Analisis}

Tepung sukun yang dihasilkan selanjutnya dianalisis karakteristiknya meliputi kadar air (AOAC, 1985), kadar amilosa (Apriyantono,1989), derajat putih (Hutching, 1999), viskositas (Fardiaz, et. al, 1992), kelarutan (Fardiaz, et. al, 1992), swelling power (Artiani, 2010), dan gugus fungsi (Hayati, 2007).

\section{HASIL DAN PEMBAHASAN}

\section{Kinetika Pengeringan Chips Sukun}

\section{Kondisi Suhu dan Kelembaban Relatif (RH) Udara Pengering}

Pengeringan adalah proses pemindahan panas dan uap air secara simultan. Gambar 1, Gambar 2 dan Gambar 3 menunjukkan perubahan suhu $\mathrm{T}_{\text {inside }}$ dan $\mathrm{T}_{\text {out }}$ serta kelembaban relatif (RH) udara selama proses proses pengeringan. Gambar tersebut menjelaskan bahwa $T_{\text {inside }}$ mengalami kenaikan dari awal bahan masuk hingga konstan pada suhu yang sama.

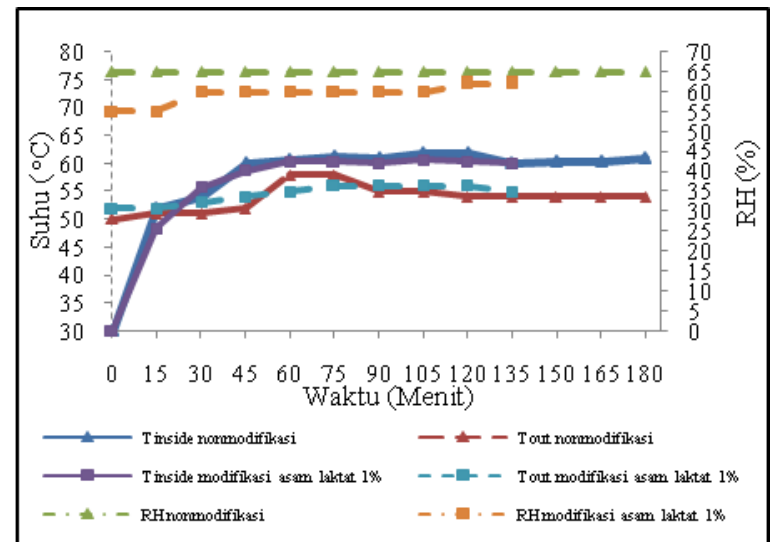

Gambar 1 Perubahan Suhu dan Kelembaban Relatif Selama Proses Pengeringan Pada Suhu $60{ }^{\circ} \mathrm{C}$

Menutut Brooker et. al., (1981) ketika suhu udara pengering $\left(\mathrm{T}_{\text {inside }}\right)$ mengalami kenaikan, udara panas akan dihembuskan melewati seluruh permukaan bahan. Akibat perbedaan suhu dimana suhu udara pengering lebih tinggi dibandingkan suhu dalam bahan, maka akan terjadi proses perpindahan panas dari lingkungan ke dalam bahan. Perpindahan ini menyebabkan terjadinya perpindahan massa air yang ada dalam bahan menuju ke permukaan dan menguap ke udara.

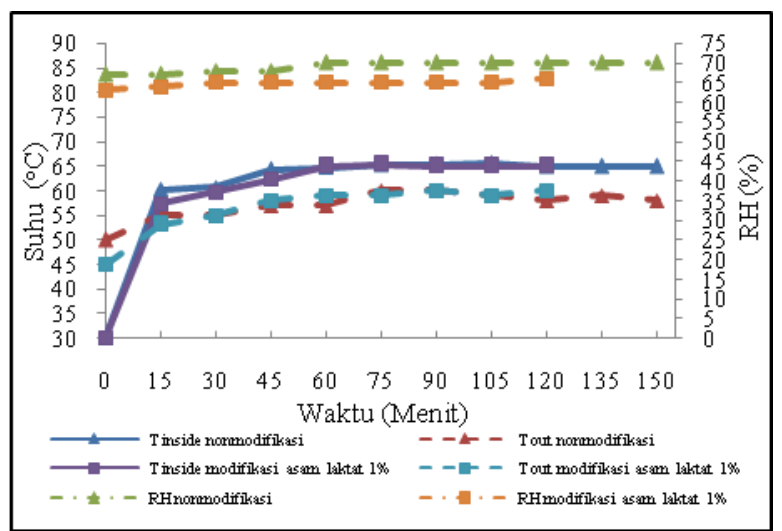

Gambar 2 Perubahan Suhu dan Kelembaban Relatif Selama Proses Pengeringan Pada Suhu $65^{\circ} \mathrm{C}$

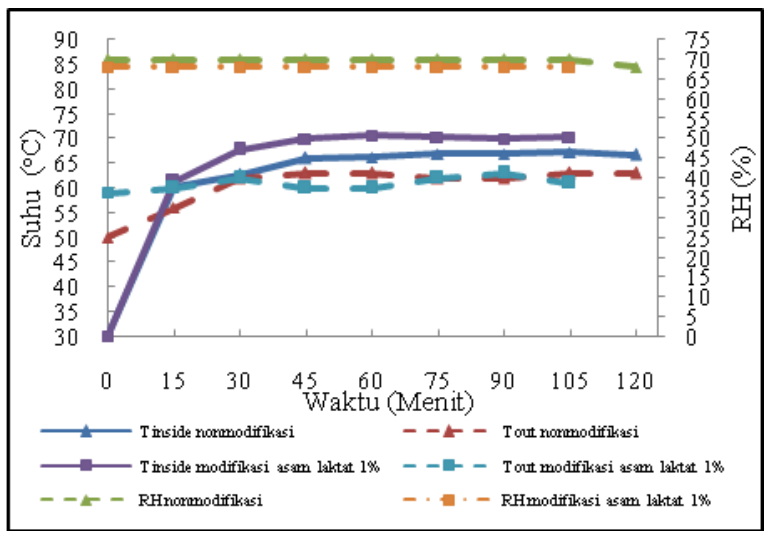

Gambar 3 Perubahan Suhu dan Kelembaban

Relatif Selama Proses Pengeringan Pada Suhu $70^{\circ} \mathrm{C}$

Kandungan uap air yang dibawa oleh udara pengering menyebabkan $\mathrm{RH}$ udara pengering cenderung meningkat sedangkan suhu udara $\left(\mathrm{T}_{\text {out }}\right)$ cenderung mengalami penurunan. Apabila kelembaban udara tinggi, maka perbedaan tekanan uap air di dalam dan di luar bahan menjadi kecil sehingga menghambat pemindahan uap air dari dalam bahan ke luar (Taufiq, 2004).

\section{Kadar Air Selama Pengeringan}

Kadar air bahan menunjukkan banyaknya kandungan air per satuan bobot bahan. Pada awal proses pengeringan, kadar air bahan menurun drastis dengan kemiringan konstan kemudian landai dan akhirnya hampir konstan. Hal ini disebabkan oleh proses perpindahan massa berupa air. Semakin lama proses pengeringan berlangsung, semakin sedikit kandungan uap 
air pada bahan karena telah terikat oleh udara pengering (Ika, 2013).

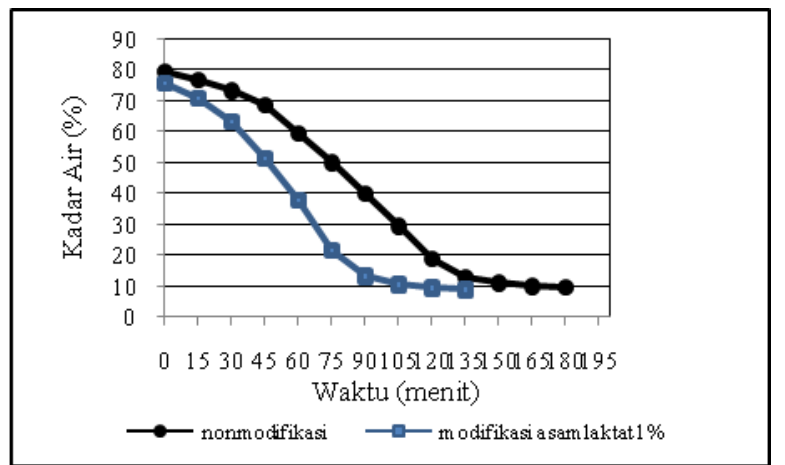

Gambar 4 Grafik Hubungan Kadar Air dengan Waktu Pada Suhu $60{ }^{\circ} \mathrm{C}$

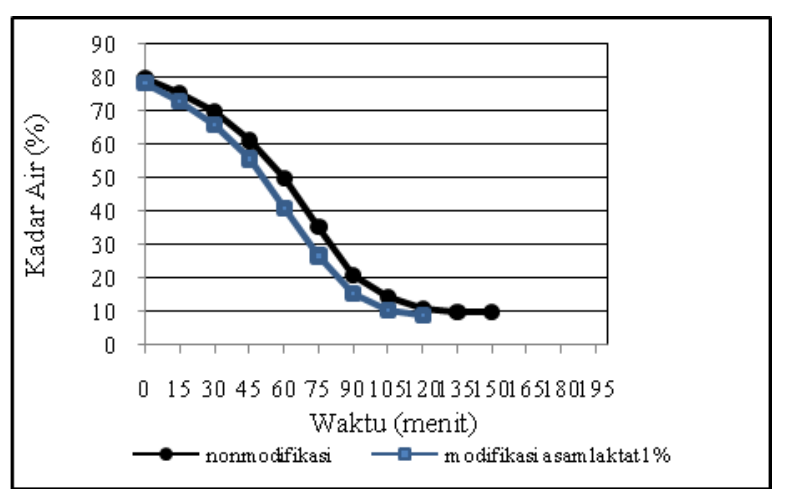

Gambar 5 Grafik Hubungan Kadar Air dengan Waktu Pada Suhu $65{ }^{\circ} \mathrm{C}$

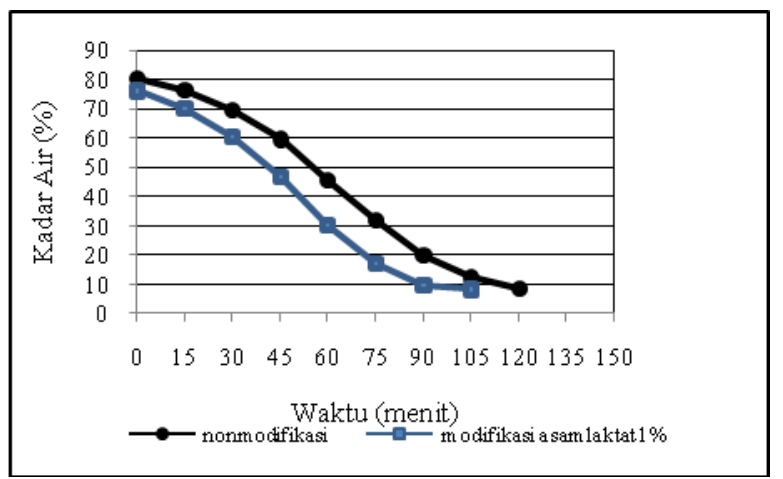

Gambar 6 Grafik Hubungan Kadar Air dengan Waktu Pada Suhu $70{ }^{\circ} \mathrm{C}$

Dari Gambar 4, Gambar 5 dan Gambar 6 bahwa kadar air chips sukun mengalami penurunan pada setiap suhu. Semakin tinggi suhu yang digunakan maka waktu pengeringan akan lebih cepat. Pengeringan chips sukun pada suhu $70{ }^{\circ} \mathrm{C}$ membutuhkan waktu pengeringan yang lebih cepat dibandingkan pengeringan chips sukun pada suhu suhu $60{ }^{\circ} \mathrm{C}$ dan $65{ }^{\circ} \mathrm{C}$. Hal ini di karenakan pada suhu yang lebih tinggi energi panas yang diberikan pada bahan yang dikeringkan akan lebih tinggi sehingga kecepatan pengeringannya akan lebih tinggi (Rusmayanti, 2004).

Menurut Yusrin (2010) modifikasi menggunakan hidrolisis asam menghasilkan pati yang strukturnya lebih renggang, sehingga air lebih mudah menguap pada waktu pengeringan. Menurut Widhaswari (2013) proses perendaman mengakibatkan tekstur bahan menjadi lunak dan berpori sehingga penguapan air selama pengeringan menjadi semakin mudah.

\section{Laju Pengeringan}

Laju pengeringan menentukan waktu untuk menurunkan kadar air produk sampai kadar air yang diinginkan. Pengeringan chips sukun yang dilakukan dalam penelitian ini menggunakan tiga level suhu pengeringan yakni $60^{\circ} \mathrm{C}, \quad 65^{\circ} \mathrm{C}$ dan $75^{\circ} \mathrm{C}$ dan dua perlakuan yakni nonmodifikasi dan modifikasi asam laktat 1\%. Dari hasil pengamatan yang telah dilakukan, laju pengeringan selama proses pengeringan mengalami penurunan.

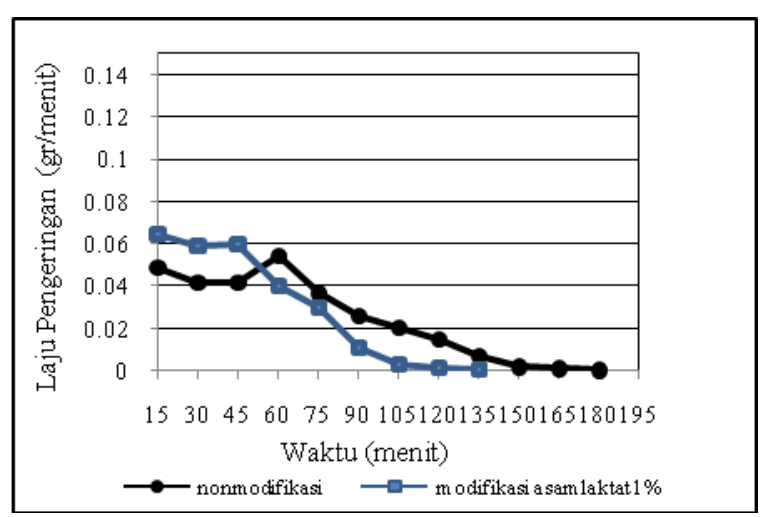

Gambar 7 Grafik Hubungan Laju

Pengeringan dengan Waktu pada Suhu $60{ }^{\circ} \mathrm{C}$

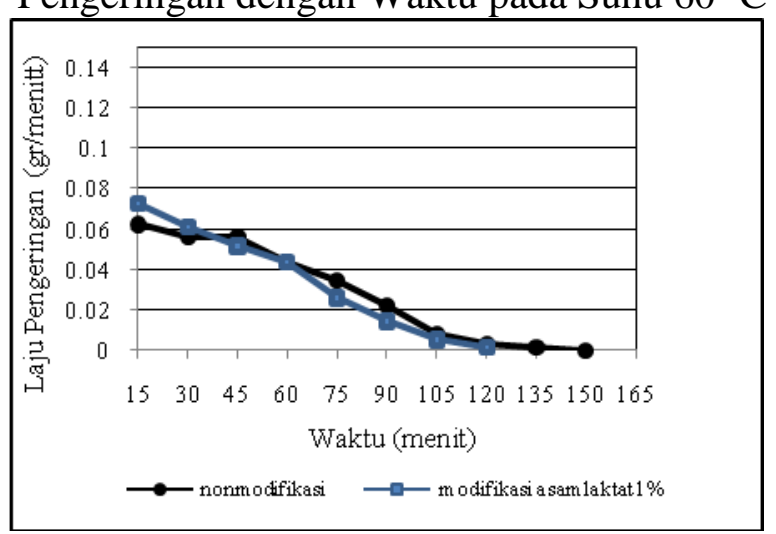

Gambar 8 Grafik Hubungan Laju Pengeringan dengan Waktu pada Suhu $65{ }^{\circ} \mathrm{C}$ 


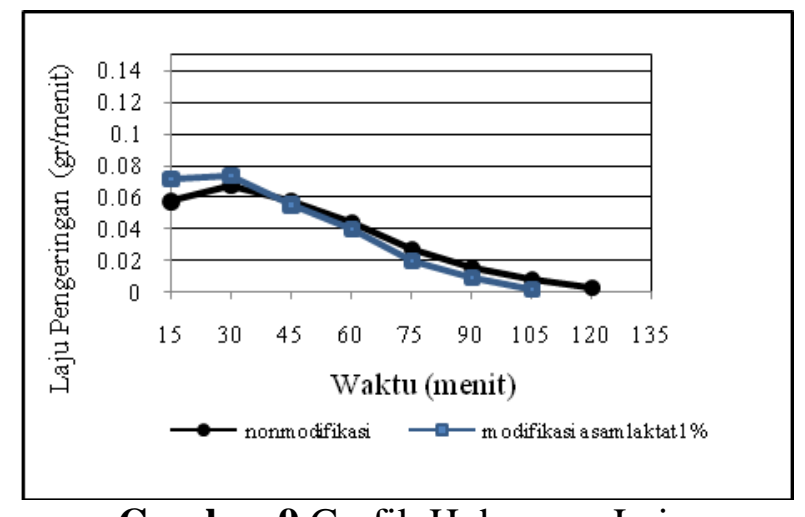

Gambar 9 Grafik Hubungan Laju

Pengeringan dengan Waktu pada Suhu $70{ }^{\circ} \mathrm{C}$

Dari Gambar 7, Gambar 8 dan Gambar 9 bahwa laju pengeringan chips sukun mengalami penurunan pada setiap suhu. Perubahan laju pengeringann terlihat fluktuatif selama pengeringan namun cenderung terus mengalami penurunan. Penurunan kadar air yang fluktuatif menjelaskan bahwa air dalam bahan masih berpotensi untuk mengalami penguapan selama periode akhir pengeringan.

Hal tersebut terjadi sebab selama proses pengeringan, selain adanya air bebas yang cenderung lebih mudah menguap selama periode awal pengeringan, adapula air terikat yaitu air yang sulit untuk bergerak naik ke permukaan bahan selama pengeringan sehingga laju pengeringan semakin lama semakin menurun (Ismandari dkk., 2008). Selain itu, laju pengeringan terendah terlihat pada suhu pengeringan 60 ${ }^{\circ} \mathrm{C}$ dan laju pengeringan tertinggi pasa suhu pengeringan $70{ }^{\circ} \mathrm{C}$. Menurut Hawa (2009) bahwa laju pengeringan semakin naik dengan bertambahnya suhu, sehingga laju pengeringan berbanding lurus dengan suhu pengeringan.

\section{Kebutuhan Energi}

Kebutuhan energi pengeringan adalah hasil penjumlahan antara energi panas yang digunakan untuk memanaskan bahan dan menguapkan air dalam bahan selama proses pengeringan.

Pada Gambar 10 menunjukkan bahwa nilai kebutuhan energi pengeringan chips sukun berkisar antara 418,24 KJ - 453,82 KJ. Nilai kebutuhan energi pengeringan chips sukun termodifikasi asam laktat $1 \%$ lebih rendah dibandingkan pengeringan chips sukun nonmodifikasi. Hal ini menurut Erika (2010) bahwa modifikasi asam menyebabkan air lebih mudah menguap saat pengeringan sehingga proses pengeringan menjadi lebih cepat, sehingga energi yang dibutuhkan lebih sedikit. Menurut Safrizal dkk (2012) semakin tinggi suhu pengeringan maka semakin tinggi kebutuhan energinya.

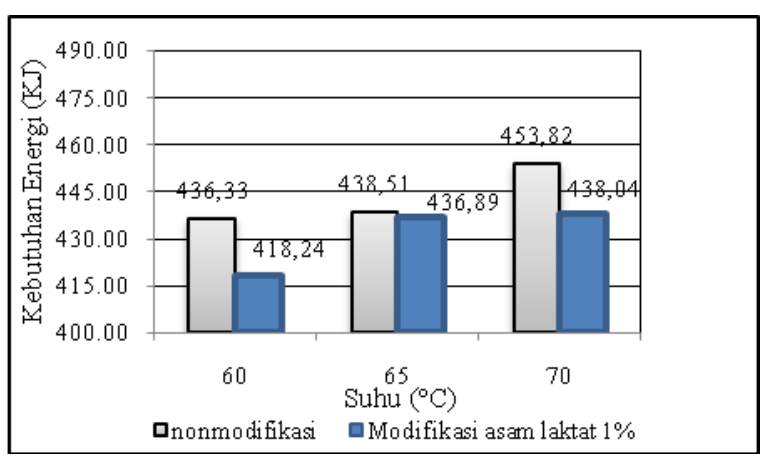

Gambar 10 Kebutuhan energi pengeringan Chips Sukun

Semakin bertambahnya waktu pengeringan akan mengakibatkan terjadinya penurunan kadar air bahan, dengan menurunnya kandungan air bahan mengakibatkan kebutuhan energi pengeringan juga akan menurun. Hal ini seperti dijelaskan dalam penelitian Sumardi (2007) bahwa proses pengeringan akan mengakibatkan kandungan uap air suatu bahan akan menguap sehingga kadar air bahan makin lama makin berkurang. Dengan berkurangnya kandungan air bahan maka energi panas yang diperlukan atau dimanfaatkan oleh bahan akan kecil. Dengan semakin kecilnya energi panas yang dipergunakan untuk pengeringan maka kebutuhan energi pengeringan juga akan mengecil.

\section{Karakteristik Tepung Sukun}

\section{Kadar Air}

Kadar air merupakan banyaknya air yang terkandung dalam bahan yang dinyatakan dalam persen. Hasil analisa menunjukkan hasil bahwa variasi suhu pengeringan dan perlakuan modifikasi asam berpengaruh nyata terhadap kadar air tepung sukun yang dihasilkan $(\alpha<0,05)$ dan ditunjukkan pada Tabel 1dan Tabel 2.

Pada penelitian Erika (2010) mengatakan bahwa pati termodifikasi dengan 
hidrolisis asam menghasilkan pati dengan struktur yang lebih renggang, sehingga air lebih mudah menguap pada waktu pengeringan.

Menurut Taufiq (2010) semakin tinggi suhu udara pengering maka makin tinggi energi panas yang dibawa udara sehingga makin banyak jumlah massa cairan yang diuapkan dari permukaan bahan. Dengan adanya kenaikan suhu maka akan menaikkan suhu bahan dan menyebabkan tekanan uap air di dalam bahan lebih tinggi daripada tekanan uap air di udara, sehingga terjadi perpindahan uap air dari bahan ke udara atau perpindahan massa. Oleh karena itu, kadar air tepung sukun termodifikasi pada suhu pengeringan $70{ }^{\circ} \mathrm{C}$ memiliki nilai terendah.

\section{Kadar Amilosa}

Amilosa merupakan fraksi terlarut dari pati yang berupa rantai lurus yang terdiri atas molekul molekul glukosa yang berikatan $\alpha$ $(1,4)$-D glukosa. Pengujian kadar amilosa ini bertujuan untuk mengetahui pengaruh modifikasi yang dilakukan pada tepung sukun dengan variasi suhu pengeringan.

Hasil analisa menunjukkan hasil bahwa variasi suhu pengeringan berpengaruh nyata terhadap kadar amilosa tepung sukun yang dihasilkan $(\alpha<0,05)$ dan ditunjukkan pada Tabel 1. Sedangkan perlakuan modifikasi asam berpengaruh nyata terhadap kadar amilosa tepung sukun yang dihasilkan $(\alpha<0,05)$ dan ditunjukkan pada Tabel 2.

Tabel 1 Pengaruh Variasi Suhu Pengeringan Terhadap Karakteristik Tepung Sukun

\begin{tabular}{|c|c|c|c|c|c|c|}
\hline $\begin{array}{l}\text { Suhu } \\
\left({ }^{\circ} \mathrm{C}\right)\end{array}$ & $\begin{array}{c}\text { Kadar air } \\
(\%)\end{array}$ & $\begin{array}{c}\text { Kadar } \\
\text { Amilosa } \\
(\%)\end{array}$ & $\begin{array}{l}\text { Derajat } \\
\text { Putih }\end{array}$ & $\begin{array}{l}\text { Viskositas } \\
\text { (Cp) }\end{array}$ & $\begin{array}{l}\text { Kelarutan } \\
(\%)\end{array}$ & $\begin{array}{c}\text { Swelling } \\
\text { Power } \\
\text { (g/g) }\end{array}$ \\
\hline 60 & $9,39 \pm 0,53^{\mathrm{a}}$ & $15,79 \pm 2,53^{\mathrm{a}}$ & $84,89 \pm 1,91^{\mathrm{a}}$ & $\begin{array}{l}6698,50 \pm \\
2182,14^{\mathrm{a}}\end{array}$ & $11,25 \pm 2,32^{\mathrm{a}}$ & $6,88 \pm 0,39^{\mathrm{a}}$ \\
\hline 65 & $9,29 \pm 0,62^{\mathrm{a}}$ & $17,84 \pm 2,93^{\mathrm{b}}$ & $84,99 \pm 2,08^{\mathrm{a}}$ & $\begin{array}{l}7954,17 \pm \\
1845,00^{\mathrm{b}}\end{array}$ & $10,94 \pm 1,78^{\mathrm{a}}$ & $6,94 \pm 0,14^{\mathrm{a}}$ \\
\hline 70 & $8,38 \pm 0,34^{b}$ & $20,22 \pm 3,93^{\mathrm{c}}$ & $84,50 \pm 1,54^{\mathrm{a}}$ & $\begin{array}{l}8593,00 \pm \\
1673,62^{b}\end{array}$ & $12,85 \pm 4,30^{\mathrm{a}}$ & $7,39 \pm 0,27^{b}$ \\
\hline
\end{tabular}

Keterangan : angka yang diikuti huruf yang sama menunjukkan tidak berbeda nyata pada taraf signifikasi $\alpha=0,05$

Tabel 2 Pengaruh Penambahan Asam Laktat Terhadap Karakteristik Tepung Sukun

\begin{tabular}{ccccccc}
\hline Sampel & $\begin{array}{c}\text { Kadar air } \\
(\%)\end{array}$ & $\begin{array}{c}\text { Kadar } \\
(\%)\end{array}$ & $\begin{array}{c}\text { Derajat } \\
\text { Putih } \\
(\%)\end{array}$ & $\begin{array}{c}\text { Viskositas } \\
(\mathrm{Cp})\end{array}$ & $\begin{array}{c}\text { Kelarutan } \\
(\%)\end{array}$ & $\begin{array}{c}\text { Swelling } \\
\text { Power } \\
(\mathrm{g} / \mathrm{g})\end{array}$ \\
\hline $\begin{array}{c}\text { Non- } \\
\text { modifikasi }\end{array}$ & $9,38 \pm 0,68^{\mathrm{a}}$ & $15,13 \pm 1,44^{\mathrm{a}}$ & $83,39 \pm 1,20^{\mathrm{a}}$ & $\begin{array}{c}6139,78 \pm \\
1218,03^{\mathrm{a}}\end{array}$ & $9,92 \pm 1,65^{\mathrm{a}}$ & $6,97 \pm 0,41^{\mathrm{a}}$ \\
$\begin{array}{c}\text { Modifikasi } \\
\text { asam }\end{array}$ & $8,66 \pm 0,45^{\mathrm{b}}$ & $20,77 \pm 2,54^{\mathrm{b}}$ & $86,19 \pm 0,86^{\mathrm{b}}$ & $\begin{array}{c}9357,33 \pm \\
970,61^{\mathrm{b}}\end{array}$ & $13,44 \pm 2,96^{\mathrm{b}}$ & $7,17 \pm 0,30^{\mathrm{a}}$ \\
laktat $1 \%$ & & & & &
\end{tabular}

Keterangan : angka yang diikuti huruf yang sama menunjukkan tidak berbeda nyata pada taraf signifikasi $\alpha=0,05$

Peningkatan kadar amilosa pada suhu yang lebih tinggi diduga disebabkan suhu pengeringan yang cukup tinggi pada proses pengeringan menyebabkan terjadinya pemutusan rantai amilosa-amilopektin penyusun granula sehingga menyebabkan rasio amilosa semakin meningkat (Jading, 2013).

\section{Derajat Putih}

Derajat putih produk tepung-tepungan pada umumnya menjadi salah satu parameter kualitasnya. Hasil analisa menunjukkan hasil bahwa variasi suhu pengeringan tidak berpengaruh nyata terhadap derajat putih tepung sukun yang dihasilkan $(\alpha<0,05)$ dan ditunjukkan pada Tabel 1. Sedangkan perlakuan modifikasi asam berpengaruh nyata terhadap derajat putih tepung sukun 
yang dihasilkan $(\alpha<0,05)$ dan ditunjukkan pada Tabel 2.

Suhu yang tinggi dan waktu pengeringan yang terlalu lama menyebabkan terjadinya perubahan warna bahan menjadi lebih gelap (Martunis, 2012). Hal serupa dijelaskan Lidiasari, et al., (2006) bahwa suhu yang tinggi dan lama pengeringan yang terlalu lama menyebabkan warna permukaan bahan menjadi gelap yang menyebabkan penurunan tingkat kecerahan warna sehingga menurunkan nilai derajat putih.

Menurut Hartanti (2013) pH rendah yang disebabkan penambahan asam laktat mempengaruhi derajat putih tepung sukun termodifikasi. Hal ini terjadi karena kemampuan asam dalam menghambat enzim fenolase pada sukun yang berpengaruh dalam browning enzimatik. Semakin rendah $\mathrm{pH}$ dalam perendaman sukun maka semakin banyak aktivitas enzim fenolase yang dapat dihambat. Sehingga tepung sukun yang dihasilkan memiliki nilai derajat putih yang tinggi. Oleh karena itu, nilai derajat putih tepung sukun termodifikasi lebih tinggi dibandingkan tepung sukun nonmodifikasi.

\section{Viskositas}

Viskositas merupakan ketahanan aliran suatu cairan (fluida) pada pengaruh tekanan. Hasil analisa menunjukkan hasil bahwa variasi suhu pengeringan berpengaruh nyata terhadap viskositas tepung sukun yang dihasilkan antara suhu pengeringan $65^{\circ} \mathrm{C}$ dan $70{ }^{\circ} \mathrm{C}$ dengan suhu pengeringan $60{ }^{\circ} \mathrm{C}$ tetapi antara suhu pengeringan $65{ }^{\circ} \mathrm{C}$ dengan $70{ }^{\circ} \mathrm{C}$ tidak berpengaruh nyata $(\alpha<0,05)$ dan ditunjukkan pada Tabel 1. Sedangkan perlakuan modifikasi asam berpengaruh nyata terhadap viskositas tepung sukun yang dihasilkan $(\alpha<0,05)$ dan ditunjukkan pada Tabel 2.

Hidrolisis menyebabkan rantai pati tereduksi dan cenderung lebih pendek sehingga mudah menyerap air. Air yang terserap pada setiap granula pati akan menyebabkan granula-granula pati mengembang (Wijayaningrum, 2009).

Selain itu, ketika pati dipanaskan, maka ikatan hidrogen antara molekul pati yang dimodifikasi akan rusak sehingga menyebabkan absorbsi air kedalam granula- granula pati. Hal ini menyebabkan pembengkakan granula yang pada akhirnya akan menyebabkan kenaikan viskositas (Medikasari, 2009).

\section{Kelarutan}

Kelarutan merupakan suatu kemampuan bahan untuk larut dalam air. Hasil analisa menunjukkan hasil bahwa variasi suhu pengeringan tidak berpengaruh nyata terhadap kelarutan tepung sukun yang dihasilkan $(\alpha<0,05)$ dan ditunjukkan pada Tabel 1. Sedangkan perlakuan modifikasi asam berpengaruh nyata terhadap kelarutan tepung sukun yang dihasilkan $(\alpha<0,05)$ dan ditunjukkan pada Tabel 2.

Kenaikan kelarutan tersebut diduga menurut Hakim (2010) karena lama waktu dan suhu pengeringan menyebabkan degradasi dari pati, sehingga rantai tereduksi dan cenderung lebih pendek dan mudah menyerap air. Kelarutan pati modifikasi meningkat karena semakin banyak rantai pendek pada pati termodifikasi yang dihasilkan setelah proses hidrolisa asam sehingga pati semakin larut dalam air (Subekti, 2008). Selain itu, kadar amilosa juga berpengaruh terhadap kelarutan. Dimana semakin tinggi kadar amilosa pati maka kelarutannya di dalam air juga akan meningkat karena amilosa memiliki sifat polar (Juliano, 1994).

\section{Swelling Power}

Swelling power menunjukkan kemampuan pati mengembang di dalam air. Swelling power yang tinggi menunjukkan semakin tinggi pula kemampuan pati mengembang dalam air. Hasil analisa menunjukkan hasil bahwa variasi suhu pengeringan berpengaruh nyata terhadap swelling power tepung sukun yang dihasilkan $(\alpha<0,05)$ dan ditunjukkan pada Tabel 1 . Sedangkan perlakuan modifikasi asam tidak berpengaruh nyata terhadap swelling power tepung sukun yang dihasilkan $(\alpha<0,05)$ dan ditunjukkan pada Tabel 2.

Kenaikan nilai swelling power ditentukan oleh lamanya waktu dan suhu pengeringan yang menyebabkan terjadinya degradasi dari pati sehingga rantai pati tereduksi dan cenderung lebih pendek 
sehingga mudah menyerap air (Hakiim, 2010). Semakin besar swelling power berarti semakin banyak air yang diserap selama pemasakan, hal ini berkaitan dengan kandungan amilosa dan amilopektin yang terkandung dalam tepung. Semakin tinggi kadar amilosa maka nilai pengembangan volume akan semakin tinggi. Hal itu karena dengan kadar amilosa yang tinggi maka akan menyerap air lebih banyak sehingga pengembangan volume juga semakin besar (Murillo, 2008).

\section{Gugus Fungsi}

Analisis gugus fungsi dilakukan dengan teknik spektrofotometer FTIR pada sampel tepung sukun. Analisis spektroskopi FTIR berguna untuk mengetahui ciri struktural senyawaan kimia pada sampel dan mendeteksi perubahan gugus fungsi akibat reaksi kimia.

Gambar 11 menunjukkan puncak serapan melebar pada bilangan gelombang $3425 \mathrm{~cm}^{-1}$ dari gugus $\mathrm{O}-\mathrm{H}$, uluran $\mathrm{C}-\mathrm{H}$ alifatik pada bilangan gelombang $2924 \mathrm{~cm}^{-1}$, karbonil pada bilangan gelombang 1651$1735 \mathrm{~cm}^{-1}, \mathrm{C}=\mathrm{N}$ pada bilangan gelombang 2083-2368 dan ikatan glikosidik pada bilangan gelombang $933-1157 \mathrm{~cm}^{-1}$.

Pada tepung sukun nonmodifikasi dengan suhu pengeringan $70 \mathrm{oC}$ serapan oleh gugus fungsi $\mathrm{C}=\mathrm{O}$ karbonil yang terdeteksi pada bilangan $1651 \mathrm{~cm}^{-1}$.

Sedangkan pada tepung sukun termodifikasi asam laktat $1 \%$ dengan suhu pengeringan $60{ }^{\circ} \mathrm{C}$ dan $70{ }^{\circ} \mathrm{C}$ terjadi serapan oleh gugus fungsi yang terbaca dengan bilangan gelombang $1735 \mathrm{~cm}^{-1}$ yang juga merupakan gugus $\mathrm{C}=\mathrm{O}$ karbonil.

Menurut Pudjihastuti (2010) bahwa semakin banyak penambahan asam laktat menyebabkan $\mathrm{pH}$ semakin rendah, sedangkan pengaruh $\mathrm{pH}$ pada pati menyebabkan penambahan pada gugus $\mathrm{C}=\mathrm{O}$ karbonil.

Gugus karbonil berkontribusi terhadap peningkatan kapasitas hidrasi (Wang, et.al. 2003). Peningkatan kapasitas hidrasi menyebabkan jumlah air terikat dalam pati semakin banyak sehingga penguapan air dari dalam bahan selama proses pengeringan semakin meningkat dan pengembangan produk menjadi semakin besar karena pembentukan struktur matrik amorph melalui ikatan hidrogen (Bertolini, et.al, 2001).

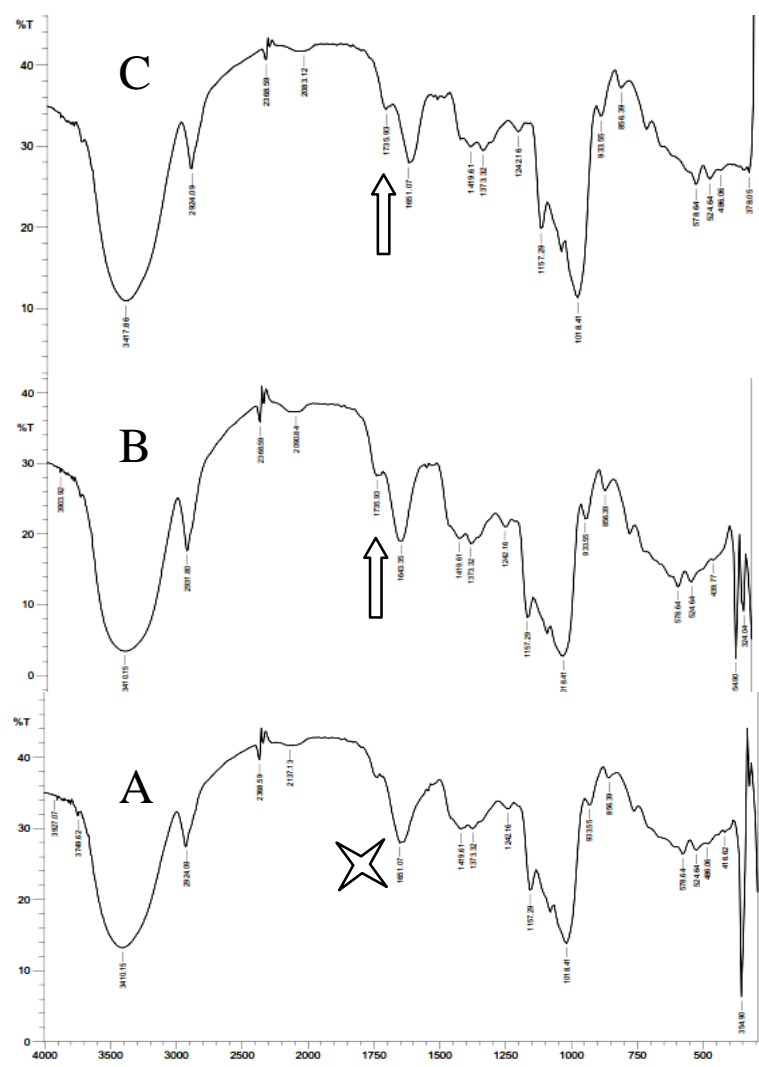

Gambar 11 Spektrum Serapan Tepung Sukun Nonmodifikasi dengan Suhu Pengeringan $70^{\circ} \mathrm{C}(\mathrm{A})$, Modifikasi dengan Suhu Pengeringan $60^{\circ} \mathrm{C}(\mathrm{B})$, Modifikasi dengan Suhu Pengeringan $70^{\circ} \mathrm{C}(\mathrm{C})$

\section{KESIMPULAN}

1. Semakin tinggi suhu pengeringan dan penambahan asam laktat menyebabkan penurunan kadar air chips sukun, mempercepat laju pengeringan dan menurunkan kebutuhan energi pengeringan.

2. Semakin tinggi suhu pengeringan dan penambahan asam laktat menyebabkan menurunnya kadar air dan derajat putih tepung sukun, meningkatnya kadar amilosa, viskositas, kelarutan dan swelling power tepung sukun. Analisis gugus fungsi (FTIR) menunjukkan adanya serapan gugus karbonil pada bilangan gelombang $1735 \mathrm{~cm}-1$ dari tepung sukun yang termodifikasi asam laktat. 


\section{SARAN}

Saran yang dapat diberikan antara lain perlu dilakukan penelitian lebih lanjut berupa analisis Scanning Electron Micrograph (SEM) untuk mengetahui karakter granula pati dari tepung sukun, analisis sudut curah atau sudut repos untuk mengetahui indeks alir tepung dan aplikasi produk berbahan tepung sukun termodifikasi.

\section{DAFTAR PUSTAKA}

[AOAC] Association Official Analitical Chemist. 1985. Official standard of Analitical Chemist. AOAC Inc. Arlington. Virgina.

Apriyantono, A., Fardiaz, D., Puspitasari, N. L., Sedarnawati dan Budijanto, S. 1989. Petunjuk Laboratorium Analisis Pangan. Pusat Antar Universitas Pangan dan Gizi, Institut Pertanian Bogor, Bogor.

Bertolini, A. C., Mestres, C., Lourdin, D., Valle, G. D and Colonna, P. 2001. RelationshipBetween Thermomechanical Properties and Baking Expansion of Sour Cassava Starch. Journal of the Science of Food and Agriculture 81 : 429-435.

Brooker, D.B., Bakker-Arkema, F.W., dan Hall, C.W. 1982. Drying Cereal Grains. The AVI Publishing Company, Inc., Westport, Connecticut.

Erika, Cut. 2010. Produksi Pati Termodifikasi dari Beberapa Jenis Pati. Jurnal Rekayasa Kimia dan Lingkungan Vol. 7, No. 3, hal. 130-137, ISSN 1412 5064.

Fardiaz, D, N. Andarwulan, Hanny Wijaya, dan Ni Luh Puspitasari. 1992. Petunjuk Laboratorium Teknik Analisis Sifat Kimia dan Fungsional Komponen Pangan. PAU pangan dan Gizi IPB, Bogor.

Gunasekaran K, Shanmugan, V and Suresh, P. 2012. Modelling and Analytical Experimental Study of Hybrid Solar Dryer Integrated with Biomass Dryer for Drying Coleus Forskohlii Stems. IPCSIT 28: $28-32$
Hakiim, Azafilmi dan Faresti Sistihapsari.2010. Modifikasi Fisik Kimia Tepung Sorgum berdasarkan Karakteristik Sifat Fisikokimia sebagai Substituen Tepung Gandum. Jurusan Teknik Kimia. Fakultas Teknik. Universitas Diponegoro.

Hartanti, Feny Dwi. 2013. Kajian Karakteristik Fisikokimia Tepung Sukun (Artocarpus communis) Termodifikasi dengan Variasi Konsentrasi Asam Laktat dan Lama Perendaman. Jurnal Teknosains Pangan Vol 2 No 4

Hawa, La Choviya, Sumardi H. S. Dan Elfira. 2009. Penentuan Karakteristik Pengeringan Lapisan Tipis Ikan Kembung (Rastrelliger sp.), Jurnal Teknologi Pertanian Vol. 10 No.3.

Hayati. 2007. Dasar-dasar Analisis Spektroskopi dalam Kusumastuti, A. 2011. Pengenalan Pola Gelombang Khas dengan Interpolasi. Jurnal CAUCHY. Vol 2. No.1. Hal 7-12.

Hutching, J.B. 1999. Food Color and Appearance. Chapman and Hall Food. Science Book. Aspen Publisher., Inc., Gaithersburg, Maryland.

Indrasti, F. 2004. Pemanfaatan Tepung Talas Belitung (Xanthosoma saginifolium) dalam Pembuatan Cookies. Skripsi Fakultas Teknologi Pertanian, Institut.

Lidiasari, E., et al. 2006. Pengaruh Suhu Pengeringan Tepung Tapai Ubi Kayu Terhadap Mutu Fisik dan Kimia Yang Dihasilkan. Jurnal Teknologi Pertanian.Universitas Sriwijaya, Sumatera Selatan.

Medikasari, et. al. 2009. Sifat Amilografi Pasta Pati Sukun Termodifikasi Menggunakan Sodium Tripolifosfat. Jurnal Teknologi Industri Dan Hasil Pertanian Volume 14, No. 2.

Murillo, C.E.C., Wang, Y.J., and Perez, L.A.B. 2008. Morphological, Physicochemical and Structural Characteristics of Oxidized Barley and Corn Starches, Starch/Stärke Vol. 60, 634-645. 
Pitojo, Setijo. 1992. Budidaya Sukun. Kanisius. Yogyakarta.

Pudjihastuti. 2010. Pengembangan Proses Inovatif Kombinasi Reaksi Hidrolisis Asam dan Reaksi Photokimia UV untu Produksi Pati Termodifikasi dari Tapioka. Thesis Universitas Diponegoro Semarang.

Retnaningtyas, Dyah Ayu dan Widya Dwi Rukmi Putri. 2013. Karakterisasi Sifat Fisikokimia Pati Ubi Jalar Oranye Hasil Modifikasi Perlakuan Stpp (Lama Perendaman Dan Konsentrasi). Jurnal Pangan dan Agroindustri Vol. 2 No 4 p.68-77.

Rusmayanti, Indri. 2006. Optimasi Pengeringan Sukun (Artocarpus Altilis) Dan Karakterisasi Tepung Sukun. Skripsi Institut Pertanian Bogor.

Safrizal, Refli, Hendri Syah, Rita Khathir. 2012. Analisis Efisiensi Pada Sistem Pengeringan Bunga Rosella (Hibiscus sabdariffa L) Menggunakan Alat Pengering Tipe Lemari. Rona Teknik Pertanian Vol. 5 No. 2.

Suarni. 2003. Tepung Sukun : Teknologi Prosesing dan Pemanfaatannya Sebagai Bahan Pangan. Proc. Penerapan Teknologi Tepat Guna Dalam Mendukung Agribisnis 2003.

Susilo, Bambang dan Rahartina W. Okaryanti. 2012. Studi Sebaran Suhu Dan Rh Mesin Pengering Hybrid Chip Mocaf. Jurnal Teknologi Pertanian Vol. 13 No. 2, 88-96.

Taufiq, Muchamad. 2004. Pengaruh Temperatur Terhadap Laju Pengeringan Jagung Pada Pengering Konvensional Dan Fluidized Bed. Skripsi. Universitas Sebelas Maret Surakarta.

Wang, Y. J., and Wang L. 2003. Physicochemical properties of Common and Waxy Corn Strach Oxidized by different level of Sodium Hypochlorite. Carbohydrate Polimers, 52:207-217.

Widhaswari, Viprilla A. dan Widya Dwi R.P. 2013. Pengaruh Modifikasi Kimia Dengan Sttp Terhadap Karakteristik
Tepung Ubi Jalar Ungu. Jurnal Pangan dan Agroindustri Vol.2 No.3 p.121-128. 